\title{
Characterisation of Natural and HDTMA-Br Modified Dijah-Monkin Bentonite Clay: FTIR, XRF, XRD and SEM
}

\section{Olukayode Gideon Oloyede ${ }^{1}$, Umar Omeiza Aroke ${ }^{1}$, Saidat Olanipekun Giwa ${ }^{1}$, Alexander Asanja Jock ${ }^{2}$}

\author{
${ }^{1}$ Abubakar Tafawa Balewa University \\ Dass road, P. M. B. 0248, Bauchi, 740272, Nigeria \\ ${ }^{2}$ University of Uyo \\ Ikpa Road, P. M. B. 1017, Akwa Ibom Ibom State, Nigeria
}

DOl: $10.22178 /$ pos. $70-12$

LCC Subject Category: QD1-65

Received 14.04.2021

Accepted 28.05.2021

Published online 31.05.2021

Corresponding Author: Olukayode Gideon Oloyede oloyede.gideon@gmail.com

(C) 2021 The Authors. This article is licensed under a Creative Commons Attribution 4.0 License (a) (1)
Abstract. In this study, Dijah-Monkin bentonite clay was modified with a cationic surfactant hexadecyltrimethylammonium bromide (HDTMA-Br) at the level of twice the cation exchange capacity (CEC). This process results in the development of hydrophobic organoclay with an improved adsorption capacity. The clay obtained from Zing LGA Taraba State, North-East Nigeria, was beneficiated and pulverised to a particle size of $125 \mu \mathrm{m}$. The modification was performed without acid activation to prevent damages to the clay's crystal structure. The organoclay was characterised for chemical composition, functional groups, mineralogical and surface morphology using X-ray fluorescence (XRF), Fourier Transform Infrared (FTIR) spectroscopy, X-ray diffraction (XRD) and scanning electron microscopy (SEM), respectively. The XRD showed an increase in the basal spacing from $15.681 \AA$ to $17.758 \AA$, while the XRF revealed a $5.35 \%$ concentration of $\mathrm{Br}$ on the modified clay, indicating successful intercalation. The FTIR spectra also revealed the appearance of symmetric and asymmetric stretching bands at $2847.7 \mathrm{~cm}^{-1}$ and $2914.8 \mathrm{~cm}^{-1}$, respectively, as a consequence of the modification, resulting in more sites for adsorption.

Keywords: Characterisation; Dijah-Monkin Bentonite Clay; Fourier Transform Infrared Spectroscopy; Hexadecyltrimethylammonium bromide; X-ray fluorescence; $X$-ray diffraction; Scanning electron microscopy; Zing-North East Nigeria.

\section{INTRODUCTION}

The modification of clay materials using various chemical/physical treatment has been found to achieve the desired surface properties for the best immobilisation performance of specific compounds. The modification process consists of altering the surface polarity of the clay minerals through intercalation with cationic surfactants $[11,20]$.

The bentonite clay essentially consists of montmorillonite, a member of the 2:1 clay family of two tetrahedrally coordinated silicon sheets covering an octahedrally coordinated aluminium ion layer as shown in Figure 1, with a range of negative charges of 0.4 to 1.0 per unit cell, averaging about 0.7 per unit cell.

The origin of layer charge is primarily in the octahedral sheet due to the substitution of $\mathrm{Mg}^{2+}$ and some $\mathrm{Fe}^{2+}$ for $\mathrm{Al}^{3+}$ and $\mathrm{Fe}^{3+}$ [10]. Bentonite was first used to designate particular, highly colloidal, plastic clay found near Fort Benton in the Cretaceous beds of Wyoming, USA [13].

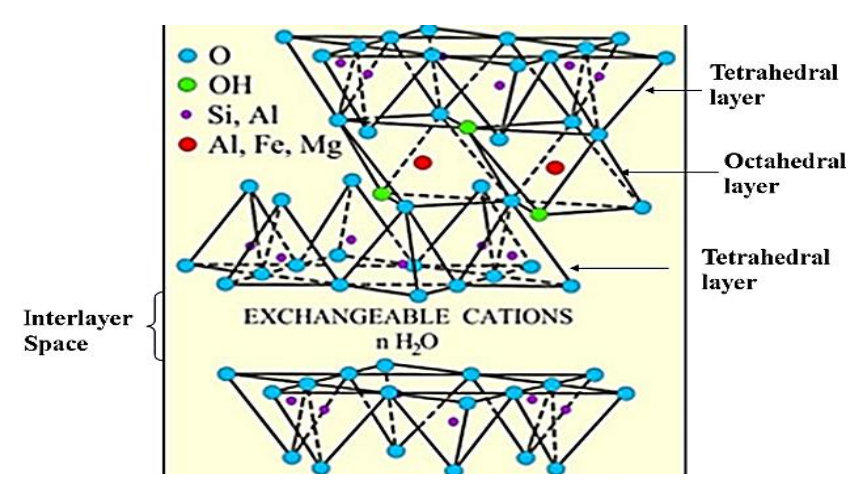

Figure 1 - Illustration of 2:1 phyllosilicate minerals of montmorillonite structure [14] 
Later the term was attributed to every plastic clay generated by the alteration of organic ash or glass emitted from volcanoes $[2,18]$.

The modification of clay surfaces with surfactant is a method to obtain organoclay by transforming organophobic to strongly organophilic surfaces and therefore increases the adsorptive capacity for adsorption of targeted/organic pollutants. This kind of surfactant-modified organobentonite has been used extensively for a wide variety of environmental applications [8]. The most common organic cations used for organoclays preparation are cationic surfactants. They are adsorbed on the clay mineral surface, and their alkyl chains render the interlayer space organophilic. As a result, the organoclay becomes an excellent adsorbent for poorly water-soluble organic species [12]. When excess HDTMA $^{+}$is present, the degree of adsorption increases due to hydrophobic interactions among tail groups. The amount of surfactant added reaches twice of clay's CEC, a complete surfactant bilayer forms on the clay surface [15].

The CEC is a term used to describe the promising ability of clay to exchange positively charged elements (cations) in an aqueous solution; it also describes the holding capacity of a soil particle or clay for cations. The cation exchange sites are primarily discovered on organic matter surfaces and clay minerals. This implies that higher clay content will result in a higher CEC value since clays have the most significant surface area. Generally, the CEC for sodium montmorillonite ranges from 80-150 mEq/100 g, while calcium montmorillonite is between $40-70 \mathrm{mEq} / 100 \mathrm{~g}$. However, Dijah-Monkin bentonite clay, which has a CEC of $47.7 \mathrm{mEq} / 100 \mathrm{~g}$ as reported elsewhere [3], is readily available in large quantity in Nigeria and is a promising candidate for various industrial applications.

This work aimed to modify the Dijah-Monkin bentonite clay with organic surfactant hexadecyltrimethylammonium bromide (HDTMA-Br) twice the cationic exchange capacity (CEC) of the clay. Further objectives were to characterise the natural and HDTMA-Br modified before the adsorption process.

\section{METHODS}

Beneficiation of Raw Dijah-Monkin Bentonite Clay. The raw bentonite clay used in this research work was collected from the deposit site at DijahMonkin town in Zing LGA, Taraba State of Nige- ria. The clay was subjected to preliminary treatment like breaking of lumps and removal of other objects. The beneficiation process was carried out according to [3] with slight modification. The powdered bulk raw Dijah-Monkin bentonite clay was soaked in de-ionised water for 24 hours and stirred at room temperature for equal mixing and homogeneity.

The clay-water mixture was allowed to age for four days for quartz impurities to sediment to the bottom, leaving the colloidal solution of clay and suspended particles at the top. The overflow was decanted and replaced with fresh tap water on each day of the sedimentation until the overflow becomes less milky and free of suspended particles. The colloid clay was collected and separated from the quartz sediments by screening through $63 \mu \mathrm{m}$ mesh size and allowed adequate time (24 hours) to settle. The thick slurry clay was sun-dried and later oven-dried to constant weight at $100{ }^{\circ} \mathrm{C}$. The dried clay was crushed, sieved with $125 \mu \mathrm{m}$ mesh and stored in polyethylene bags for subsequent experiments.

Preparation of HDTMA-Br modified bentonite adsorbent. The cationic surfactant (HDTMA-Br) was imported from Xiamen Xm-innovation Chemical Co. LTD, China. It has a purity of $99 \%$ and a molecular weight of $364.45 \mathrm{~g} / \mathrm{mol}$ and was used without any further treatment. To obtain HDTMA-bentonite, $100 \mathrm{~g}$ of the beneficiated bentonite was dispersed in $500 \mathrm{~mL}$ distilled water; the solution was stirred with a high-speed stirrer for 2 hours until a clear solution was obtained. The organic modifier was weighed (based on bentonite clay's $2.0 \times$ CEC) and dissolved in $500 \mathrm{~mL}$ distilled water until all organic modifier dissolves in water. The two solutions were mixed and stirred under $\mathrm{HJ}-3 \mathrm{D}$ Constant temperature magnetic stirrer for 24 hours. The mixed solution was then precipitated with a high-speed centrifuge (3500-4000 rpm), and the supernatant was decanted. The solid part (organoclay) was washed four times with deionised water and dried in an oven at $60{ }^{\circ} \mathrm{C}$ for 20 hours. The final organoclay was pulverised, sieved into the $100 \mu \mathrm{m}$ mesh size and stored in a desiccator for further use.

The amount of surfactant used was calculated based on CEC of Dijah-Monkin bentonite clay using equation (1):

$$
\text { Weight of surfactant }(\mathrm{g})=\mathrm{n} \times \mathrm{CEC} \times \mathrm{A} \times \mathrm{B}
$$

where $A$ is the weight of bentonite clay $(\mathrm{g})$, and $\mathrm{B}$ is the molecular weight of surfactant $(\mathrm{g} / \mathrm{mol}), \mathrm{n}$ is the ratio to be used [7]. 
Instruments for Characterisation. The $\mathrm{pH}$ of the sample was determined by soaking the solid clay in water at a ratio of $1: 5$, and the solution $\mathrm{pH}$ was measured with a pH meter (model ST2100F Biocotech, China). The value was compared with the $\mathrm{pH}$ scale to determine the acidity or alkalinity of the clay sample

The FTIR spectral spectra were recorded with an FTIR Spectrophotometer (model Cary 630 FTIR, Agilent Technologies, USA). The spectra were obtained from the solid samples at a resolution of $1 \mathrm{~cm}^{-1}$ within the range of $4000-650 \mathrm{~cm}^{-1}$. Also, the elemental composition was determined using X-ray Fluorescence (XRF; model ARL9900, Thermo Scientific, USA). The equipment uses basic parameters to determine the propagation of X-rays from the tubes through the optical path to the detector.

The X-ray diffraction (XRD) data for both natural and modified were obtained using an x-ray diffractometer (model mini Flex600, Rigaku, Japan) at a fixed power source $(40 \mathrm{~kW}, 40 \mathrm{~mA})$. The measurements were obtained at a scanning rate

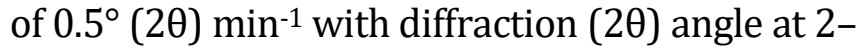
$90^{\circ}$. The basal spacing was calculated using Braggs equation $(\mathrm{n} \lambda=2 \mathrm{~d} \sin \theta)$, where $\mathrm{n}$ is the integer $(n=1), \lambda$ is the wavelength of incidence wave $(\lambda=0.15418 \mathrm{~nm})$, and $d$ is the spacing between the incident ray and the scattering planes.

The surface morphology of both natural and modified bentonite clay was obtained using a scanning electron microscope (SEM, model phenon pro X, Eindhoven, Netherlands) which was carried out at $15 \mathrm{kV}$ and a size of $200 \mu \mathrm{m}$.

\section{RESULTS AND DISCUSSION}

The $\mathrm{pH}$ of the natural clay was 6.6 , while the $\mathrm{pH}$ of the HDTMA modified clay was 5.15. Most clay suspensions have $\mathrm{pH}$ ranging from 4.2 to 7 [3].
This implies that the natural clay is less acidic compared with the HDTMA modified clay. The extended $\mathrm{C}-\mathrm{H}$ group of the $\mathrm{HDTMA}^{+}$chain intercalated on the clay could be responsible for this development.

FTIR Spectroscopy. Figures 2 and 3 show the spectra of natural and modified Dijah-Monkin bentonite clay in the wavenumber range of $4000-650 \mathrm{~cm}^{-1}$, while the vibrational frequencies and the assignments are presented in Table 1. The bands corresponding to the water molecules in the interlayers and the structural hydroxyl groups in the clay layers are in the region between 3750 and $3500 \mathrm{~cm}^{-1}$.

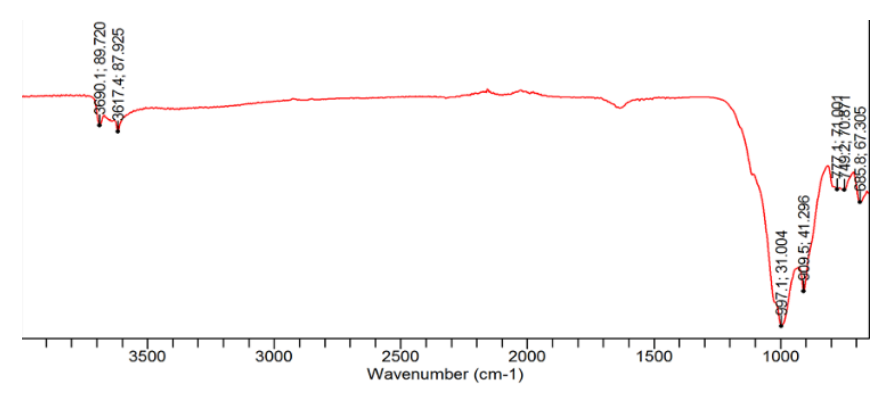

Figure 2 - FTIR Spectrum of Dijah-Monkin Bentonite Clay

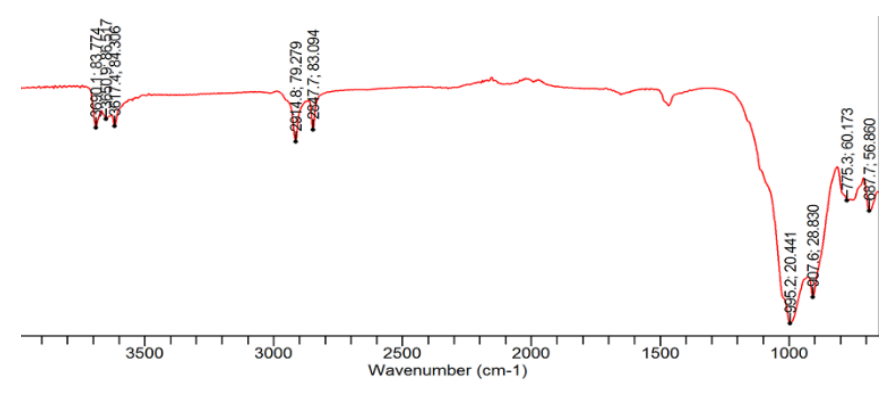

Figure 3 - FTIR Spectrum of Modified Dijah-Monkin Bentonite Clay

Table 1 - Vibrational Frequencies and Assignments for Natural and Modified Dijah-Monkin Clay

\begin{tabular}{|l|l|l|l|l|}
\hline \multicolumn{2}{|c|}{$\begin{array}{c}\text { Natural Dijah-Monkin Bentonite } \\
\text { IR peak Bond type }\end{array}$} & \multicolumn{2}{c|}{$\begin{array}{c}\text { Modified Dijah-Monkin Bentonite } \\
\text { IR peak Bond type }\end{array}$} & Remarks \\
\hline 685.8 & OH- deformation & 687.7 & OH- deformation & Shifted upward \\
\hline 749.2 & Al-O-Si (silicate bonds) & & & Disappears \\
\hline 777.1 & Si-O deformation & 775.3 & Si-O deformation & Shifted downward \\
\hline 909.5 & Al-Al-OH & 907.6 & Al-Al-OH & Shifted downward \\
\hline 997.1 & Si-O planar stretching & 995.2 & Si-O planar stretching & Shifted downward \\
\hline & & 2847.7 & $\mathrm{CH}_{3}$-R symmetric stretching & Appeared \\
\hline & & 2914.8 & $\mathrm{CH}_{2}$-R asymmetric stretching & Appeared \\
\hline 3617.4 & OH- stretching & 3617.4 & OH stretching & Unaffected \\
\hline & & 3650.9 & Free OH stretching & Appeared \\
\hline 3690.1 & Structural OH stretching & 3690.1 & Structural OH stretching & Unaffected \\
\hline
\end{tabular}


In comparison and the characteristic silicate bonds are found between 1200 and $700 \mathrm{~cm}^{-1}$ [19]. When modification was carried out with HDTMA $^{+}$, the peak at $3650.9 \mathrm{~cm}^{-1}$ representing free $\mathrm{OH}$ stretching bonds appeared while the adsorption band $2960-2820 \mathrm{~cm}^{-1}$ can be considered belonging to the $\mathrm{C}-\mathrm{H}$ groups $\mathrm{HDTMA}^{+}$. Also, the $\mathrm{OH}$ - adsorption peaks shift from 685.8 to $687.7 \mathrm{~cm}^{-1}$, while the peaks of the structural $\mathrm{OH}^{-}$ stretching remain unchanged. Furthermore, the peak of the silicate bonds disappeared being the consequence of $\mathrm{HDTMA}^{+}$exchanging the $\mathrm{Al}^{3+}$ groups. This shows that the appearing peaks representing $\mathrm{C}-\mathrm{H}$ groups and the free $\mathrm{OH}$ stretching groups will provide more available attachment sites for adsorption.

$X$-ray fluorescence analysis. This was conducted to reveal the chemical compositions in the modified and unmodified Dijah-Monkin bentonite clay. The chemical analysis presented in Table 2 shows that the bentonite clays consist mainly of silica and alumina with metallic oxides such as $\mathrm{Fe}_{2} \mathrm{O}_{3}, \mathrm{~K}_{2} \mathrm{O}$, CaO, etc., present as minor.

Table 2 - XRF Analysis of Natural and Modified DijahMonkin Bentonite Clay

\begin{tabular}{|c|c|c|}
\hline $\begin{array}{c}\text { Composition } \\
\text { (wt\%) }\end{array}$ & $\begin{array}{c}\text { Natural } \\
\text { Bentonite }\end{array}$ & $\begin{array}{c}\text { Modified } \\
\text { Bentonite }\end{array}$ \\
\hline $\mathrm{SiO}_{2}$ & 62.61 & 63.44 \\
\hline $\mathrm{Al}_{2} \mathrm{O}_{3}$ & 21.10 & 19.05 \\
\hline $\mathrm{TiO}_{2}$ & 1.23 & 0.71 \\
\hline $\mathrm{Fe}_{2} \mathrm{O}_{3}$ & 8.24 & 6.34 \\
\hline $\mathrm{MnO}$ & 0.13 & 0.20 \\
\hline $\mathrm{CaO}$ & 1.18 & 1.04 \\
\hline $\mathrm{Ag}_{2} \mathrm{O}$ & 0.85 & 0.91 \\
\hline $\mathrm{V}_{2} \mathrm{O}_{5}$ & 0.05 & 0.05 \\
\hline $\mathrm{K}_{2} \mathrm{O}$ & 4.61 & 2.88 \\
\hline $\mathrm{Br}$ & 0.00 & 5.35 \\
\hline $\mathrm{Total}$ & 100 & 100 \\
\hline
\end{tabular}

The most abundant components are $\mathrm{Si}$ and $\mathrm{Al}$, which are the smectite clay group [5]. Generally, the $\mathrm{Al}_{2} \mathrm{O}_{3} / \mathrm{SiO}_{2}$ ratio obtained is 0.34 and 0.30 for natural and HDTMA-Br modified Dijah-Monkin clays, respectively, which is in close agreement with the expected value (i. e. 0.33 ) for montmorillonite [1].

The concentration of $\mathrm{Fe}_{2} \mathrm{O}_{3}$ is responsible for the reddish and brownish colours in clay samples. For the Dijah-Monkin bentonite clay, the $\mathrm{Fe}_{2} \mathrm{O}_{3}$ concentration was $8.24 \%$ and higher than the iron content concentration of $6.34 \%$ in the modified Dijah-Monkin bentonite.

This explained the high reddish colour in the natural clay as compared to the modified. The presence of a moderate amount of $\mathrm{CaO}$ could be attributed to the occurrence of carbonate such as calcite in the sediments, and there is no detectable amount of $\mathrm{Na}_{2} \mathrm{O}$, which may suggest that the predominant clay mineral is a Ca-rich type [16].

Furthermore, it was observed that with the clay intercalation at twice the CEC, the concentration of $\mathrm{Br}$ in the modified clay was at $5.35 \%$, which implied intercalation by HDTMA + via hydrophobic interactions among surfactant tail groups, indicating bilayer modification with a corresponding decrease in $\mathrm{K}_{2} \mathrm{O}$ (4.61\% to 2.88\%) and $\mathrm{CaO}$ $(1.18 \%$ to $1.04 \%)$ as shown in Figure 4.

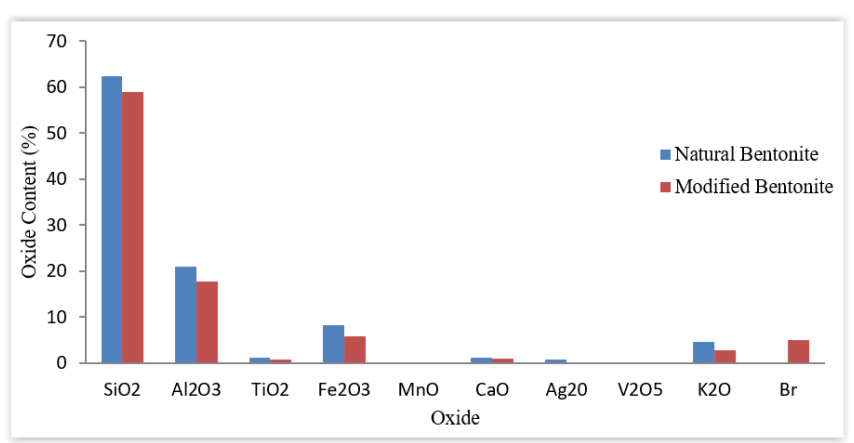

Figure 4 - Chemical composition of natural and modified Dijah-Monkin bentonite clay

A chemical formula calculation could be performed for the natural bentonite with the XRF data using the approach proposed by Foster [9]. The calculation procedure and half-cell formula are presented in Table 3, and the one layer structural formula for natural Dijah-Monkin bentonite clay determined was $\left[\left(\mathrm{Al}^{3+}{ }_{2.82} \mathrm{Ti}^{4+}{ }^{4+}{ }_{0.11} \quad \mathrm{Fe}^{3+}{ }^{3+} 077\right.\right.$ $\left.\left.\mathrm{Mn}^{2+}{ }_{0.01}\right)^{-0.76} \quad\left(\mathrm{Si}^{4+}{ }^{4.74} \quad \mathrm{Al}^{3+}{ }_{0.26}\right)^{-0.26} \quad \mathrm{O}_{20}(\mathrm{OH})_{4}\right]^{-}$ ${ }^{0.51}\left(\mathrm{Ca}^{2+} 0.15 \mathrm{~K}^{+} 0.73\right)^{+0.88}$. The result compared favourably with the structural formula obtained for the natural Dijah-Monkin bentonite clay for one $\begin{array}{llll}\text { layer unit } & \mathrm{K}_{0.722} & \mathrm{Ca} 0.155 & {\left[\mathrm{Si}_{7.686}\right]^{\mathrm{iv}}}\end{array}$ $\left[\mathrm{Al}_{3.054} \mathrm{Ti}_{0.113} \mathrm{Fe}^{3+}{ }_{0.761}\right]^{\text {vi }} \mathrm{O}_{20}(\mathrm{OH})_{4}$ reported by [3]. Both structural formulas were found to be in close agreement, with silicon occupying all the tetrahedral sites and aluminium occupied twothirds of the octahedral sites while potassium and calcium are exchangeable. The superscripts "iv and vi" are used to indicate tetrahedrally and octahedrally coordinated ions, respectively [6]. 
Table 3 - Calculation of Structural Formula for Natural Dijah-Monkin Bentonite Clay

\begin{tabular}{|c|c|c|c|c|c|c|c|c|}
\hline Compound & Percent & $\begin{array}{c}\text { Molecular } \\
\text { weight }\end{array}$ & $\begin{array}{l}\text { Cationic } \\
\text { valency }\end{array}$ & $\begin{array}{l}\text { Gram equivalent } \\
\text { of cationic } \\
\text { constituents }\end{array}$ & $\begin{array}{l}\text { Cationic } \\
\text { valence per } \\
\text { unit cell }\end{array}$ & $\begin{array}{l}\text { Cations per } \\
\text { unit cell }\end{array}$ & & Charge \\
\hline $\mathrm{SiO}_{2}$ & $62.3 \div$ & 60.04 & $\times 4$ & $=4.151 \div 0.134$ & $=30.9776 \div 4$ & $\begin{array}{l}7.7444 \\
0.2556 \\
8.0000\end{array}$ & $\begin{array}{l}\text { tetrahedral } \\
\text { group }\end{array}$ & +0.2556 \\
\hline $\mathrm{Al}_{2} \mathrm{O}_{3}$ & $21.0 \div$ & 101.96 & $\times 6$ & $=1.236 \div 0.134$ & $=9.224 \div 3$ & $\begin{array}{l}(3.0747) \\
2.8191\end{array}$ & \multirow[t]{3}{*}{$\begin{array}{l}\text { octahedral } \\
\text { group }\end{array}$} & \multirow[t]{3}{*}{-0.7614} \\
\hline $\mathrm{TiO}_{2}$ & $1.22 \div$ & 79.9 & $\times 4$ & $=0.061 \div 0.134$ & $=0.4552 \div 4$ & 0.1138 & & \\
\hline $\mathrm{Fe}_{2} \mathrm{O}_{3}$ & $8.20 \div$ & 159.7 & $\times 6$ & $=0.308 \div 0.134$ & $=2.2985 \div 3$ & 0.7662 & & \\
\hline \multirow[t]{3}{*}{$\mathrm{MnO}$} & $0.13 \div$ & 70.93 & $\times 2$ & $=0.0037 \div 0.134$ & $=0.0276 \div 2$ & $\underline{\underline{0.0138}}$ & & $\begin{array}{l}\text { Composite } \\
\text { layer } \\
\text { charge } \\
-0.5058\end{array}$ \\
\hline & & & & Sum(-Si and $\mathrm{Al})$ & $=2.7815$ & & & \\
\hline & & & & Octahedral $\mathrm{Al} \times 3$ & $\begin{array}{l}+8.4573 \\
11.2386 \\
-12.000 \\
-0.7614 \\
\end{array}$ & $\begin{array}{l}\text { (Octahedral } \\
\text { charge) }\end{array}$ & & \\
\hline $\mathrm{CaO}$ & $1.17 \div$ & 56.08 & $\times 2$ & $=0.0407 \div 0.134$ & $=0.3037 \div 2$ & 0.1519 & \multirow{2}{*}{$\begin{array}{l}\text { Interlayer } \\
\text { cation } \\
\text { charge }\end{array}$} & \multirow[t]{2}{*}{$+\underline{+0.8795}$} \\
\hline $\mathrm{K}_{2} \mathrm{O}$ & $4.59 \div$ & 94.20 & $\times 2$ & $\begin{array}{l}=\underline{0.0975} \div 0.134 \\
5.8942 \\
5.8942 \div 44=\underline{0.134}\end{array}$ & $=0.7276 \div 1$ & $\begin{array}{l}\underline{0.7276} \\
\underline{\underline{0.8795}}\end{array}$ & & \\
\hline
\end{tabular}

Structural formula (half-cell)- $\left[\left(\mathrm{Al}^{3+}{ }_{1.41} \mathrm{Ti}^{4+}{ }_{0.06} \mathrm{Fe}^{3+} 0.38 \mathrm{Mn}^{2+}{ }_{0.007}\right)^{-0.38}\left(\mathrm{Si}^{4+}{ }_{3.87} \mathrm{Al}^{3+}{ }_{0.13}\right)^{-0.13} \mathrm{O}_{10}(\mathrm{OH})_{2}\right]^{-}$ ${ }^{0.25}\left(\mathrm{Ca}^{2+}{ }_{0.08} \mathrm{~K}^{+} 0.36\right)^{+0.44}$

XRD of natural and HDTMA-Br modified DijahMonkin bentonite clay. XRD can determine the structural geometry in the layer silicates of clays, and this also identifies impurities present in the clay (Figures 5-8).

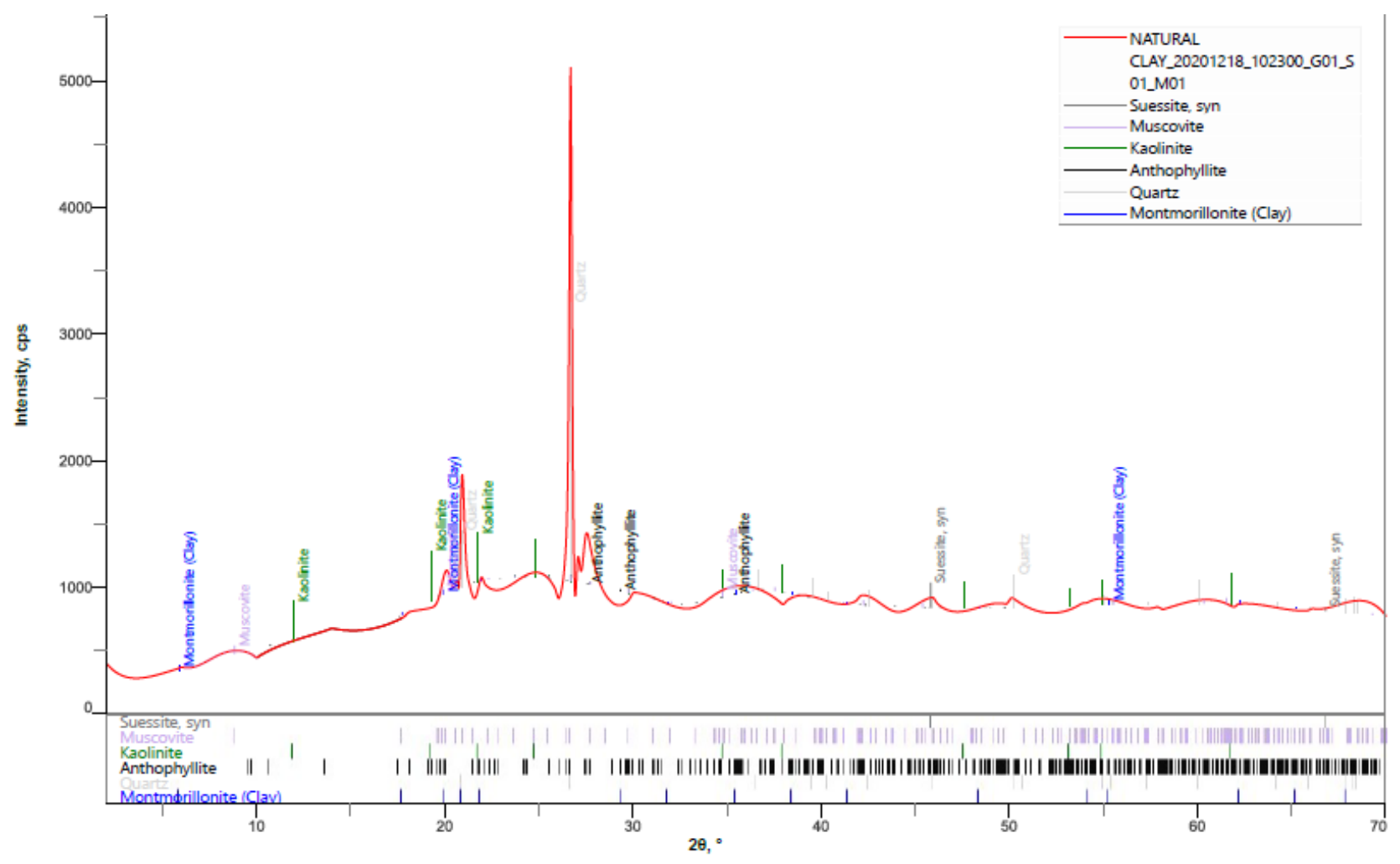

Figure 5 - XRD pattern for natural Dijah-Monkin bentonite clay 


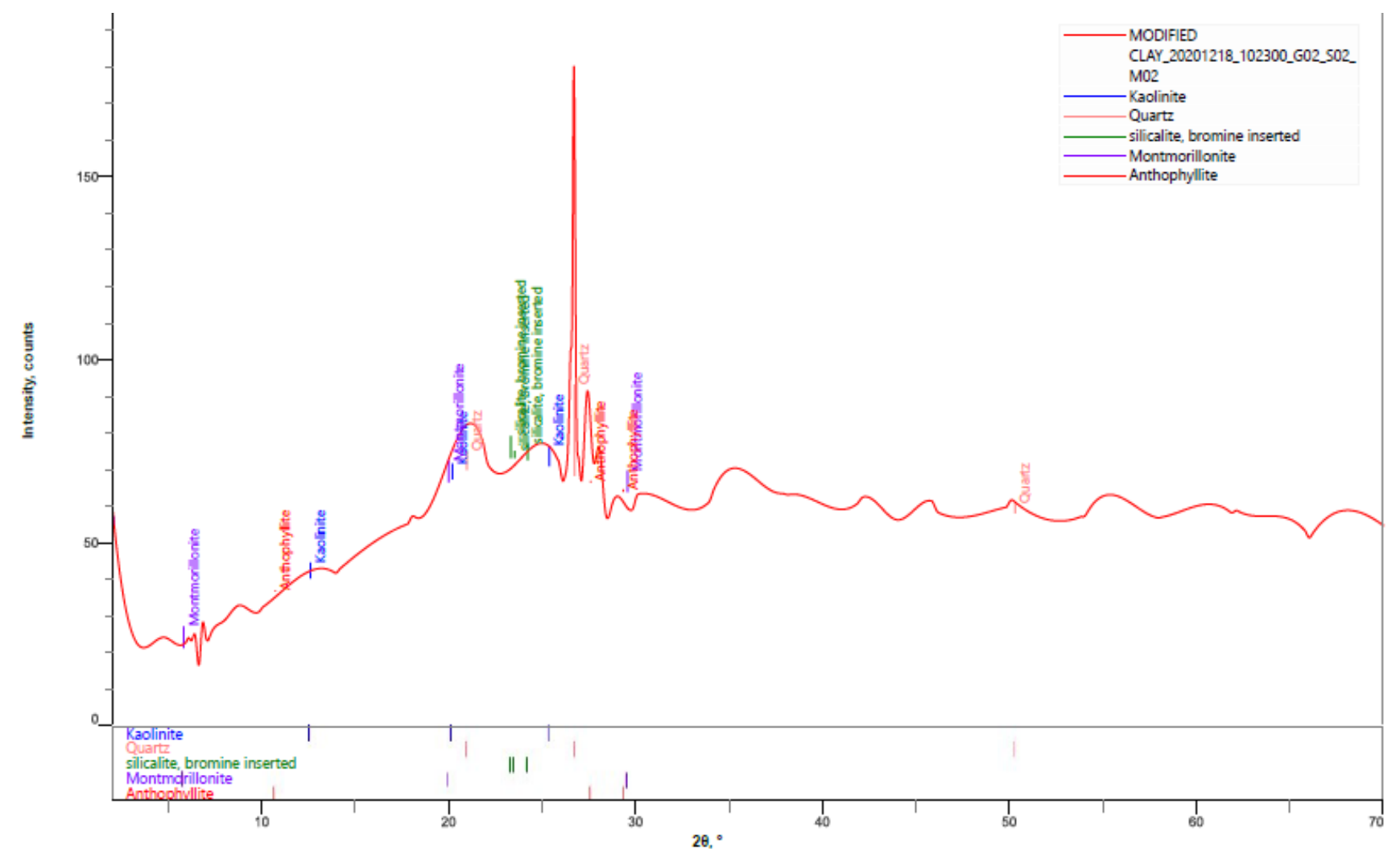

Figure 6 - XRD pattern for modified Dijah-Monkin bentonite clay

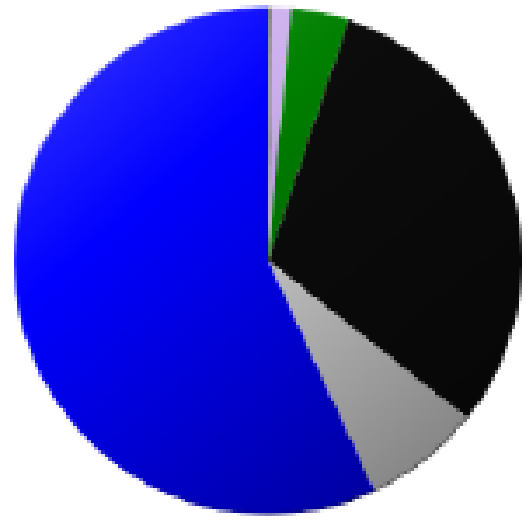

Suessite, syn : $0.24(6) \%$

Muscovite: $1.2(13) \%$

Kaolinite: $3.7(5) \%$

Anthophyllite : $30(6) \%$

Quartz : 7.5(10)\%

Dontmorilonite.. : $57(6) \%$

Figure 7 - Percentage mineral composition for natural Dijah-Monkin bentonite clay

This technique offers information on the basal spacings of organoclays, and this supports the molecular structure configuration of surfactants intercalated within clay layers [17].

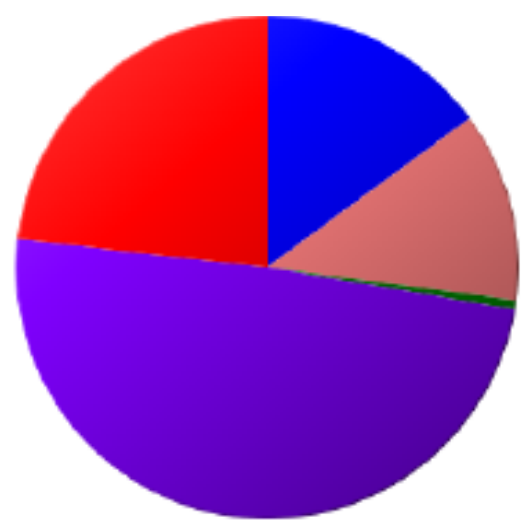

Kaolinite : 15(4)\%

Quartz : 12(4)\%

silicalite, bro.. : $0.58(10) \%$

Montmorillonite : $49(8) \%$

Dnthophylite : $23(6) \%$

Figure 8 - Percentage mineral composition for modified Dijah-Monkin bentonite clay

The XRD patterns for natural Dijah-Monkin bentonite clay shows the presence of $57 \%$ montmorillonite (M), with other constituents such as 
quartz (Q), Anthophyllite, muscovite, suessite and kaolinite accounting for the remaining 43\% (Figures 5, 7). However, the montmorillonite component reduced to $49 \%$ coupled with the appearance of $0.58 \%$ bromide (Figure 6, 8).

Furthermore, the first montmorillonite peak represents the do01 spacing of an intercalated layer of the sample. Thus the d001 spacing of natural Dijah-Monkin bentonite clay at $5.64^{\circ}$ is $15.681 \AA$, and the HDTMA-Br modified Dijah-Monkin bentonite clay at $4.98^{\circ}$ is $17.758 \AA$. This shows a significant increase in the spacing after modification. Thus it implies interlayer intercalation of the surfactant, and this is in close agreement with the result obtained by [4] where the do01 spacing of the HDTMA-Br modified bentonite clay increased from $12.06 \AA$ for original bentonite to 21.85, 35.87 and $36.46 \AA$ for 1.0, 2.0 and 3.0 CEC respectively.

SEM of natural and HDTMA-Br modified DijahMonkin bentonite clay. The textural properties, along with the surface morphology, play an essential role in identifying pores that could allow adsorption to proceed. The surface morphology of natural and HDTMA-Br modified Dijah-Monkin bentonite are shown in Figure 9 and 10, respectively. The micrograph of the natural bentonite grains (Figure 9) consists of several irregular shapes forming an aggregated mass due to several flaky particles stacked together in agglomerate, which implies a heterogeneous surface morphology [3].

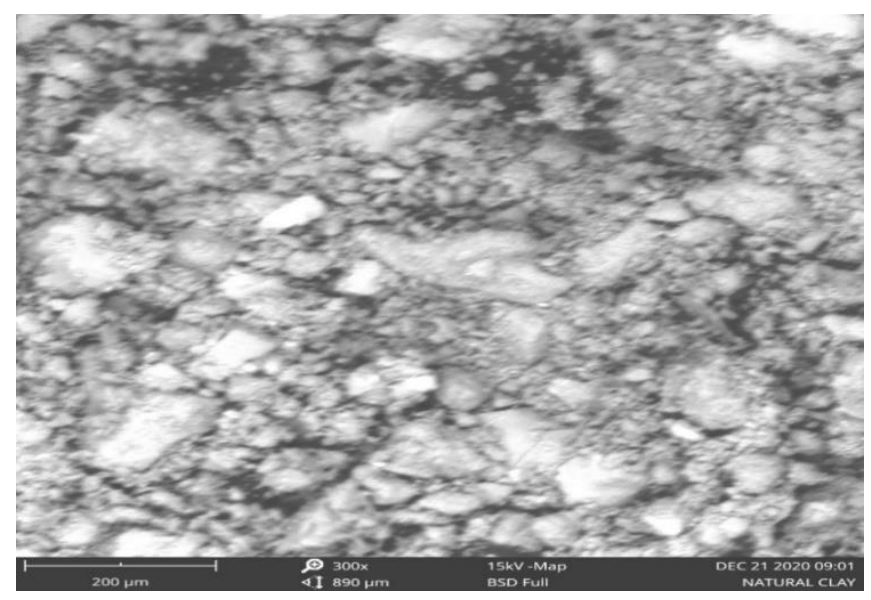

Figure 9 - SEM image for natural Dijah-Monkin bentonite clay

However, significant changes were observed in the morphology after modification with HDTMA$\mathrm{Br}$ at 2.0 Clay's CEC. The modified showed that many small and aggregated particles form plates with relatively flat layers, resulting in more voids responsible for improved clay adsorption capacity.

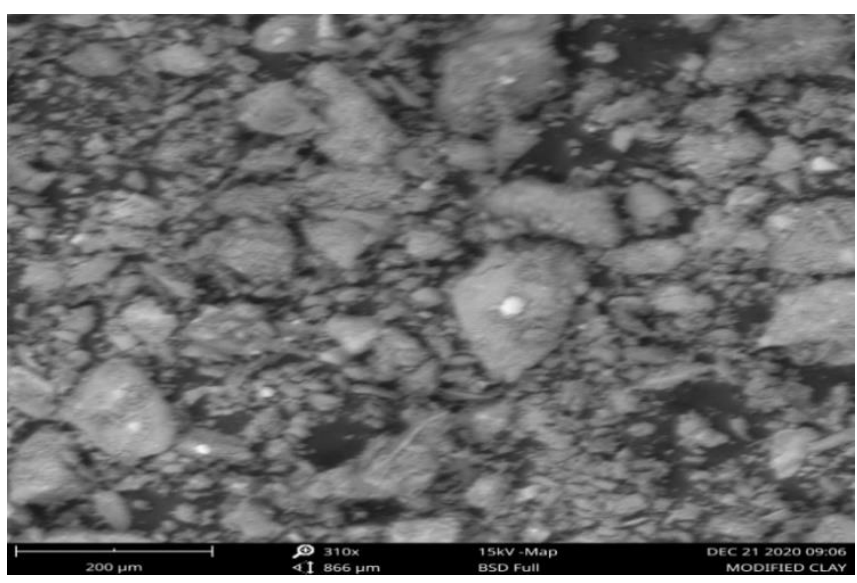

Figure 10 - SEM image for HDTMA-Br modified DijahMonkin bentonite clay

\section{CONCLUSIONS}

Dijah-Monkin bentonite clay was successfully intercalated with HDTMA-Br, and the following conclusions can be drawn from this study as presented below.

1. The natural Dijah-Monkin bentonite clay $\mathrm{pH}$ is 6.60 while HDTMA-Br modified $\mathrm{pH}$ is 5.15, which revealed a slight shift towards the acidic range and implied the intercalation of the HDTMA ${ }^{+}$long chain.

2. The FTIR spectra for HDTMA-Br modified Dijah-Monkin revealed peaks at $2847.7 \mathrm{~cm}^{-1}$ and $2914.8 \mathrm{~cm}^{-1}$, which are the consequence of the intercalation making more sites available for adsorption.

3. The XRF of HDTMA-Br modified Dijah-Monkin revealed a $5.35 \%$ concentration of $\mathrm{Br}$, which implies successful intercalation of the surfactant on the Dijah-Monkin bentonite clay surface. The one-layer structural formula for the natural Dijah-Monkin bentonite clay obtained was $\left[\left(\mathrm{Al}^{3+}{ }_{2.82}\right.\right.$ $\left.\mathrm{Ti}^{4+}{ }_{0.11} \mathrm{Fe}^{3+} 0.77 \quad \mathrm{Mn}^{2+}{ }_{0.01}\right)^{-0.76}\left(\mathrm{Si}^{4+}{ }_{7.74} \mathrm{Al}^{3+}{ }_{0.26}\right)^{-0.26}$ $\left.\mathrm{O}_{20}(\mathrm{OH})_{4}\right]^{-0.51}\left(\mathrm{Ca}^{2+} 0.15 \mathrm{~K}^{+} 0.73\right)^{+0.88}$.

4. The XRD patterns showed the do01 spacing of natural clay at $5.64^{\circ}$ is $15.681 \AA$ while the HDTMA-Br modified clay at $4.98^{\circ}$ is $17.758 \AA$. This implies that the presence of HDTMA+ surfactant ion led to an increase in the d001 spacing, indicating successful intercalation on the surface 
of the clay, indicating that the modified clay will perform better in the adsorption process.

5. The SEM micrograph for both natural and modified revealed significant changes in the morphology. The HDTMA-Br modified showed that many small and aggregated particles form plates with relatively flat layers, resulting in more voids.

\section{CONFLICTS OF INTEREST}

The authors declare no conflict of interest.

\section{REFERENCES}

1. Abdou, M. I., Al-sabagh A.M., \& Dardir, M. M. (2013). Evaluation of Egyptian bentonite and nanobentonite as drilling mud. Egyptian Journal of Petroleum, 22(1), 53-59. doi: 10.1016/j.ejpe.2012.07.002

2. Abu-Jdayil, B. (2011). Rheology of sodium and calcium bentonite-water dispersions: Effect of electrolytes and aging time. International Journal of Mineral Processing, 98(3-4), 208-213. doi: 10.1016/j.minpro.2011.01.001

3. Alexander, J. A., Ahmad Zaini, M. A., Abdulsalam, S., El-Nafaty, U. A., \& Aroke, U. O. (2016). Physicochemical characteristics of surface modified Dijah-Monkin bentonite. Particulate Science and Technology, 36(3), 287-297. doi: 10.1080/02726351.2016.1245689

4. Apiniom, N., Supachai, S., Suparerk, A., Jantrawan, P. (2008). The effect of surfactant concentration on the interlayer structure of organoclay. Chiang Mai Journal of Science, 35(1), 199-205.

5. Araujo, A. L. P. de, Bertagnolli, C., Silva, M. G. C. da, Gimenes, M. L., \& Barros, M. A. S. D. de. (2013). Zinc adsorption in bentonite clay: influence of $\mathrm{pH}$ and initial concentration. Acta Scientiarum. Technology, 35(2). doi: 10.4025/actascitechnol.v35i2.13364

6. Aroke, U., El-Nafaty, A., Osha, O. (2013). Properties and Characterisation of Kaolin Clay from Alkaleri, North-Eastern Nigeria. International Journal of Emerging Technology and Advanced Engineering, 3(11), 387-392.

7. Chanra, J., Budianto, E., \& Soegijono, B. (2019). Surface modification of montmorillonite by the use of organic cations via conventional ion exchange method. IOP Conference Series: Materials Science and Engineering, 509, 012057. doi: 10.1088/1757-899x/509/1/012057

8. Dultz, S. (2000). Organophilic bentonites as adsorbents for radionuclides II. Chemical and mineralogical properties of HDPy-montmorillonite. Applied Clay Science, 16(1-2), 15-29. doi: 10.1016/s0169-1317(99)00042-3

9. Foster, M. (1951). The importance of the exchangeable magnesium and cation-exchange capacity in the study of montmorillonitic clays. American Mineralogist, 36(9-10), 717-730.

10. Inam, D. (2005). Organoclay preparation for anionic contaminant removal from water (Master's thesis), Middle East Technical University.

11. Jaynes, W. F., \& Boyd, S. A. (1991). Clay Mineral Type and Organic Compound Sorption by Hexadecyltrimethlyammonium-Exchanged Clays. Soil Science Society of America Journal, 55(1), 43-48. doi: 10.2136/sssaj1991.03615995005500010007x

12. Kooli, F., Liu, Y., Alshahateet, S. F., Messali, M., \& Bergaya, F. (2009). Reaction of acid activated montmorillonites with hexadecyl trimethylammonium bromide solution. Applied Clay Science, 43(3-4), 357-363. doi: 10.1016/j.clay.2008.10.006

13. Kutlic, A., Bedekovic, G., \& Sobota, I. (2012). Bentonite processing. Rudarsko-geološko-naftni zbornik, 24, 61-65.

14. La bentonite. (n. d.). Bentonite structure. Retrieved April 1, 2021, from http://www.bentonite.it/bentonite-structure.php

15. Li, Z. (1999). Sorption Kinetics of Hexadecyltrimethylammonium on Natural Clinoptilolite. Langmuir, 15(19), 6438-6445. doi: 10.1021/la981535x 
16. Nweke, O. M., Igwe, E. O., \& Nnabo, P. N. (2015). Comparative evaluation of clays from Abakaliki Formation with commercial bentonite clays for use as drilling mud. African Journal of Environmental Science and Technology, 9(6), 508-518. doi: 10.5897/ajest2015.1904

17. Park, Y., Ayoko, G. A., Horváth, E., Kurdi, R., Kristof, J., \& Frost, R. L. (2013). Structural characterisation and environmental application of organoclays for the removal of phenolic compounds. Journal of Colloid and Interface Science, 393, 319-334. doi: 10.1016/j.jcis.2012.10.067

18. Stanković, N., Logar, M., Luković, J., Pantić, J., Miljević, M., Babić, B., \& Radosavljević-Mihajlović, A. (2011). Characterisation of bentonite clay from "Greda" deposit. Processing and Application of Ceramics, 5(2), 97-101.

19. Tomul, F., \& Balci, S. (2007). Synthesis and characterisation of Al-Pillard interlayered bentonite. G. U. Journal of Science, 21(1), 21-31.

20. Wibulswas, R., White, D. A., \& Rautiu, R. (1999). Adsorption of Phenolic Compounds from Water by Surfactant-Modified Pillared Clays. Process Safety and Environmental Protection, 77(2), 88-92. doi: 10.1205/095758299529857 